\title{
Analysis of the third and fourth cell cycles of mouse early development*
}

\author{
R. K. W. Smith and M. H. Johnson \\ Department of Anatomy, University of Cambridge, Downing Street, Cambridge CB2 3DY, U.K.
}

\begin{abstract}
Summary. The third (4-cell) and fourth (8-cell) cell cycles of early mouse development have been analysed in populations of blastomeres synchronized to the preceding cleavage division. DNA content was measured microdensitometrically. The entry of blastomeres into these cell cycles showed considerable heterogeneity both within and between individual embryos. This heterogeneity was greater in the fourth than in the third cell cycle. The component phases of the third cell cycle were estimated as $G_{1}=1 \mathrm{~h}, S=7 \mathrm{~h}$, and $\mathrm{G}_{2}+\mathrm{M}=2-5 \mathrm{~h}$, and those of the fourth cell cycle as $G_{1}=2 h, S=7 h$, and $G_{2}+M=1-3 h$.
\end{abstract}

\section{Introduction}

An understanding of the kinetics of the cell cycle in embryonic cells is important for two reasons. First, it is possible that cellular receptivity to developmental signals and hence progress into a new state of differentiation and/or developmental commitment may be limited to a particular phase of the cell cycle. Second, the passage of time during embryogenesis may be measured by the number of cell cycles (or some component thereof) elapsed since a prior time-setting event, such as, for example, fertilization.

We are interested in the process whereby cell diversity is generated in the very early mouse embryo, and in the interaction that evidently occurs between the temporal programme within the cells of the embryo and the spatial signalling among these cells (Johnson, 1985). To understand and analyse the nature of this temporal programme, it is first necessary to describe the early cell cycles and their constituent parts. A number of studies, using a variety of techniques, have analysed the first two cell cycles (reviewed by Molls, Zamboglou \& Streffer, 1983). However, few studies have been made of the third and fourth cell cycles in which important cell interactions lay down a primary axis of differentiation within the embryo (Johnson, 1985). We have investigated these cell cycles by use of a microdensitometric assay for the DNA content of individual blastomere nuclei.

\section{Materials and Methods}

Embryo collection. Female mice, 4-6 weeks old, of the MF1 strain (Olac, Bicester, Oxon, U.K.) or $\mathrm{F}_{1} \mathrm{LAC}$ strain (C57BL $\times \mathrm{CBA} / \mathrm{Ca}$, bred in the laboratory) were superovulated by an intraperitoneal injection of PMSG (Intervet, Cambridge, U.K.; 5-10 i.u. depending on size of animal) followed $48 \mathrm{~h}$ later by intraperitoneal injection of the same dose of hCG (Intervet). For fertilization in vivo, MF1 females were paired with a stud male (HC-CFLP, Hacking and Churchill, Ltd, Alconbury, U.K.) overnight. The presence of a vaginal plug was taken as a sign of mating. Mated mice were killed by cervical dislocation $48 \mathrm{~h}$ after the hCG injection, and the embryos were recovered by flushing the oviducts with pre-warmed $\left(37^{\circ} \mathrm{C}\right.$ ) Medium 2 (Fulton \& Whittingham,

\footnotetext{
* Reprint requests to Dr M. H. Johnson.
} 
1978) containing $4 \mathrm{mg}$ bovine serum albumin/ml [M2 + BSA]. The numbers of late 2-cell (2c), 3 -cell ( $3 c)$ and early 4-cell (4c) embryos were recorded (dividing cells were recorded as one cell) and all 2-cell embryos were transferred to Medium 16 (Whittingham, 1971) containing $4 \mathrm{mg} \mathrm{BSA} / \mathrm{ml}$ [M16 + BSA] under oil and pre-equilibrated at $37^{\circ} \mathrm{C}$ and in $5 \% \mathrm{CO}_{2}$ in air. During experimental manipulation, culture dishes were removed from the incubator for the minimum possible period and were viewed on the heated stage $\left(37^{\circ} \mathrm{C}\right)$ of a Wild binocular dissecting microscope.

Assay for DNA content. Individual embryos were placed into squares scored onto an acidcleaned glass microscope slide and the position of each embryo was noted. Excess medium was removed and the embryos were allowed to dry in air. Freshly dissected mouse liver was washed in sterile phosphate buffered saline (Oxoid, U.K., pH 7.3) and smeared onto each slide. Samples were fixed, stained by the Feulgen reaction as described by Bolton, Oades \& Johnson (1984), and stored at $-20^{\circ} \mathrm{C}$ in the dark for a maximum of 1 week before densitometric quantitation. Embryonic nuclei and liver nuclei were measured for their integrated absorbance at $560 \mathrm{~nm}$ wavelength, with the $\times 100$ objective of a Vickers M86 microdensitometer (procedures described by Smith \& Johnson, 1985). At each reading session, between 40 and 60 liver nuclei were read in order to obtain $2 \mathrm{C}$ and 4C DNA values and also to ensure that the stain had not faded if the readings were taken over more than 1 day. For each embryonic nucleus, the average of two readings was taken. Blurred, damaged or obscured nuclei were excluded (5-10\% of the total). Overlapping nuclei were scanned together, and the average of two readings halved to give the mean value for each nucleus. This procedure was considered to be legitimate as the values obtained were always in the correct range, and the nuclei were from the same time point. For measurements of the third cell cycle, the percentage of overlapping nuclei was $5-10 \%$ while in the fourth cell cycle it was $20-25 \%$. The number of nuclei in each embryo and the nuclei undergoing mitosis were noted. When results from different experiments were pooled, the ratio of the 2C DNA values from each experiment was used as a 'standardizing factor' and assigned the value of 100 arbitrary units. Curve fitting to graph points was carried out using the Statistical Analysis System-Non-linear Curve Fitting Procedure. Limits of the lengths of $G_{1}, S$ and $G_{2}$ phases were estimated from points of maximal inflection.

\section{Results}

Variation between and within embryos in the transition from 2-cell to 4-cell blastomeres

In 5 experiments a total of 6712 -cell embryos were scored at 1-h intervals for division to yield 3-cell or 4-cell embryos. Subsequently all 3-cell embryos were scored at 1 -h intervals until the other $(1 / 2)$ blastomere had divided. From the data collected, it was possible to estimate the variation in division times within an embryo (Table 1, column 2). In $85 \%$ of embryos second cleavage occurred in both blastomeres within a period of $2 \mathrm{~h}$ or less. In contrast, within the population of embryos as a whole there was a period of $13 \mathrm{~h}$ over which blastomeres divided. There is therefore much greater variation between than within embryos in blastomere division times.

\section{$D N A$ replication in the 4-cell embryo}

The large degree of heterogeneity amongst embryos in the time of transition from 2-cells to 4-cells made it impossible to map out the third cell cycle in terms of hours after hCG. However, $42 \%$ of 2-cell embryos divide to 4-cells within a period of $1 \mathrm{~h}$, and these embryos were collected and cultured for periods of up to $13 \mathrm{~h}$ before they were scored for cell number and DNA content. The results of 5 such experiments are pooled in Fig. 1. From these data the length of the $G_{1}$ phase of the 3 rd cell cycle was estimated as $1 \mathrm{~h}$, the $S$ phase as $7 \mathrm{~h}$ and $\mathrm{G}_{2}+\mathrm{M}$ as between 2 and $5 \mathrm{~h}$. 
Table 1. Variation within individual mouse embryos of time for completion of division of all blastomeres

(1)

Time span over which* all blastomeres in one embryo had divided (h)

\begin{tabular}{rrrr}
\hline 1 & 42 & 16 & 29 \\
2 & 85 & 51 & 61 \\
3 & 96 & 69 & 78 \\
4 & 98 & 86 & 91 \\
$>4$ & 100 & 100 & 100 \\
\hline
\end{tabular}

* Because observation intervals of $1 \mathrm{~h}$ were used, these figures represent the maximum time for completion of division.

† A population of 4-cell embryos that had been formed by division of both 2-cell blastomeres within a $l-h$ period.

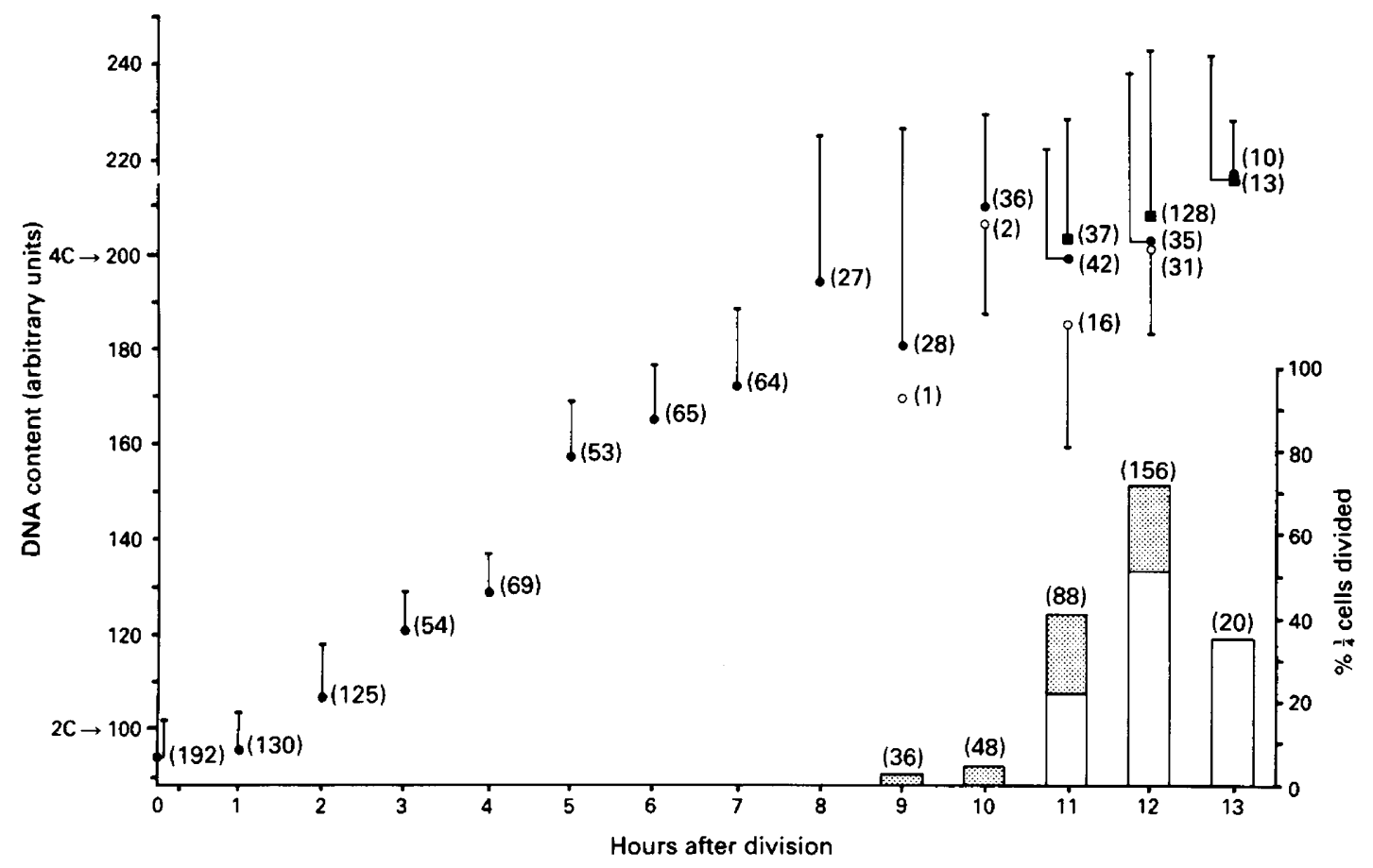

Fig. 1. DNA content of nuclei of individual blastomeres within intact mouse embryos, measured by microdensitometric analysis at a wavelength of $560 \mathrm{~nm}$ after staining with Feulgen reagent, and plotted against hours after division to the 4-cell stage. Each point is the mean of all the blastomeres harvested at each time in a total of 5 experiments (normalized to the liver standard used in each case). The number of nuclei scored at each time is indicated beside each point. Bars indicate one standard deviation. 0 = value from $1 / 4$ blastomere (or 'cell'); $\boldsymbol{v}=$ sum of values from each $1 / 8$ blastomere in a $2 / 8$ pair derived by division of $1 / 4 ; 0=$ value from mitotic $1 / 4$ blastomere. The histogram shows the percentage of individual $1 / 4$ blastomeres divided or dividing to $2 / 8$ at given times after division to $1 / 4$ blastomeres. The stippled area within each bar refers to the percentage of $1 / 4$ blastomeres in mitosis and the number in parentheses indicates the number of blastomeres studied at each time. 
Table 2. Summary of values for phases of the first four cell cycles of mouse embryos

\begin{tabular}{lcccc}
\hline & \multicolumn{3}{c}{ Length of phase (h) } & \\
\cline { 2 - 4 } \multicolumn{1}{c}{ Cell cycle } & $\mathrm{G}_{1}$ & $\mathrm{~S}$ & $\mathrm{G}_{2}+\mathrm{M}$ & \multicolumn{1}{c}{ References* } \\
\hline First (1-cell stage) & $4 \cdot 5-12 \dagger$ & $4-7$ & $1-8$ & $1,3,6,8,9,10,11$ \\
Second (2-cell stage) & $0-1 \cdot 3$ & $4-7$ & $12-18$ & $2,4,5,7,9,10$ \\
Third (4-cell stage) & $1-1 \cdot 5$ & 7 & $0 \cdot 5-5$ & $5,9,10,12$ \\
Fourth (8-cell stage) & 2 & 7 & $1-3$ & 9,12 \\
\hline
\end{tabular}

* 1, Luthardt \& Donahue, 1973; 2, Luthardt \& Donahue, 1975; 3, Abramczuk \& Sawicki, 1975; 4, Siracusa et al., 1975; 5, Sawicki et al., 1978; 6, Domon, 1980; 7, Bolton et al., 1984; 8, Krishna \& Generoso, 1977; 9, Streffer et al., 1980; 10, Molls et al., 1983; 11, Howlett \& Bolton, 1985; 12, This paper.

$\dagger$ Includes completion of meiosis II in most studies.

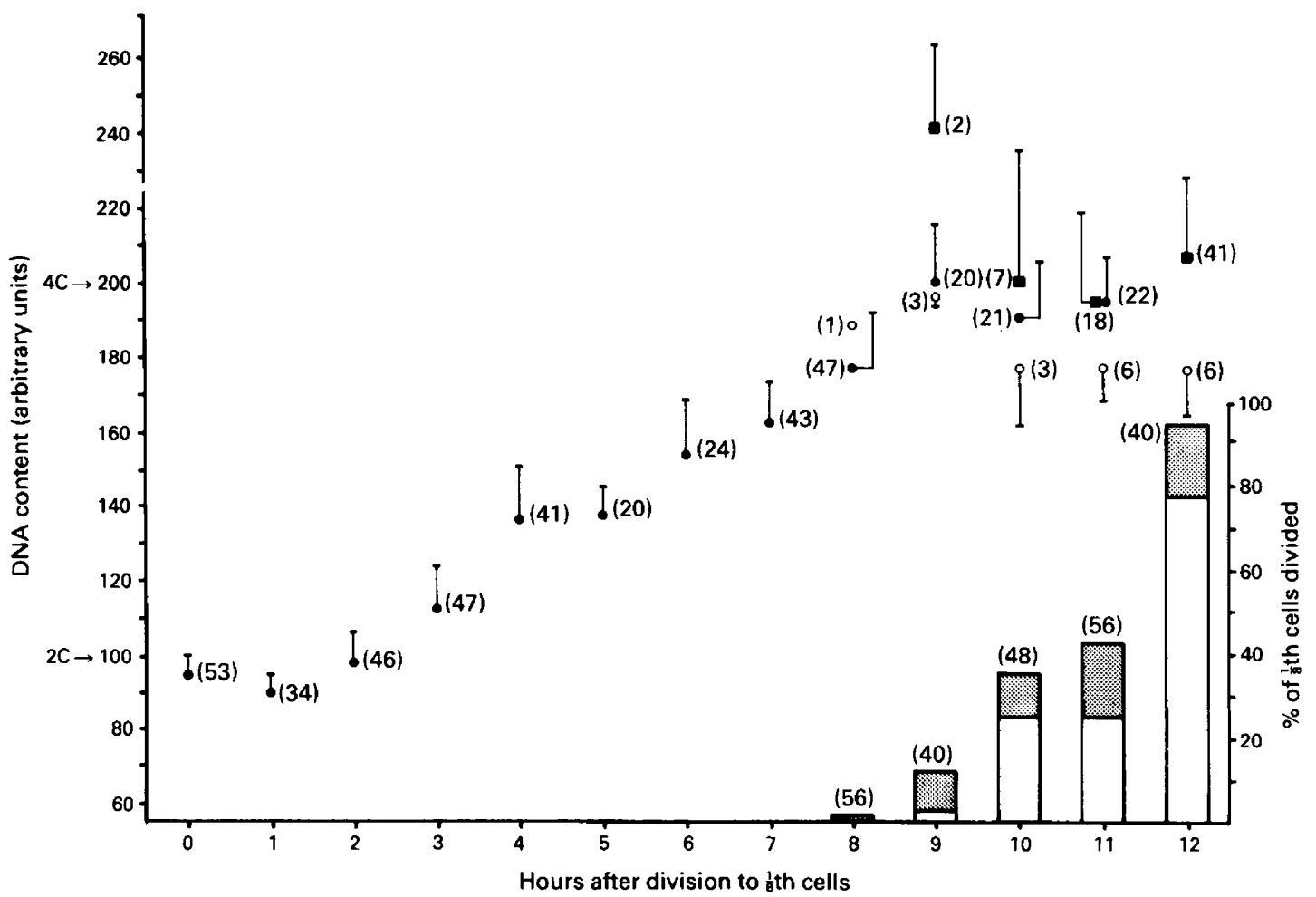

Fig. 2. DNA content of individual blastomere nuclei (measured by microdensitometric analysis at a wavelength of $560 \mathrm{~nm}$ after staining with Feulgen reagent) plotted against hours after division to $1 / 8$ blastomeres. Data from 3 experiments were combined (after normalizing to the liver standard used in each) and the number of nuclei scored is indicated beside each point. Bars show one standard deviation. $=$ values for $1 / 8$ blastomeres; $\mathbf{D}=$ sum of values for each $1 / 16$ blastomere in a $2 / 16$ couplet derived by division of $1 / 8 ; O=$ value for mitotic $1 / 8$ blastomere. The histogram bars depict the percentage of $1 / 8$ blastomeres that have undergone or are undergoing cleavage at given times after division to $1 / 8$ blastomeres. The percentage in mitosis is represented by the stippled area and the number in parentheses indicates the number of blastomeres studied at each hour. 


\section{Variation between and within embryos in the transition from the 4-cell to the 8-cell stage}

Two protocols were used in this experiment. In Protocol 1, synchronous populations of 4-cell embryos, derived from embryos in which both blastomeres of a 2-cell embryo had divided within $1 \mathrm{~h}$, were cultured through the entire third cell cycle and into the fourth cell cycle. These synchronized embryos were observed at 1-h intervals from $10 \mathrm{~h}$ in culture onwards, and any blastomeres that had divided within each embryo were recorded. In Protocol 2, a random population of late 4-cell embryos was examined every hour and any divisions of blastomeres were recorded. The results for both protocols are shown in Table 2, columns 3 and 4 . As expected, there was greater within-embryo variation at the 4-cell to 8-cell transition for randomly selected 4-cell embryos (column 3) than for synchronized 4-cell embryos (column 4). Moreover, within-embryo heterogeneity of blastomeres increased with advancing developmental stage, as is seen by comparing columns 2 and 3 in Table 1. Similarly, in the proportion of embryos as a whole there was an increase in the period over which all blastomeres divided from $13 \mathrm{~h}$ ( 2 to 4 transition) to $15 \mathrm{~h}$ ( 4 to 8 transition).

\section{$D N A$ replication in the 8 -cell embryo}

Any 4-cell embryos that had divided to 8 cells within $1 \mathrm{~h}$ were cultured for up to $12 \mathrm{~h}$ before they were scored for cell number and DNA content. The results are shown in Fig. 2. From this figure we estimate that $G_{1}$ lasts for $2 \mathrm{~h}$, the $S$ phase for $7 \mathrm{~h}$ and $\mathrm{G}_{2}+\mathrm{M}$ for $1-3 \mathrm{~h}$.

\section{Discussion}

We have measured the length of the phases of the third and fourth cell cycles by use of populations of blastomeres synchronized to the preceding cleavage division. Such an approach was essential in light of the developmental heterogeneity amongst blastomeres within and between embryos, a heterogeneity that tends to increase progressively during development (this report; Barlow, Owen \& Graham, 1972; Kelly, Mulnard \& Graham, 1978; Streffer, Van Beuningen, Molls, Zamboglou \& Schulz, 1980; Chisholm, Johnson, Warren, Fleming \& Pickering, 1985). The selection of cleavage as a reliable expression of the cell cycle does not imply that cytokinesis itself is part of the regulatory system of developmental time; indeed, there is clear evidence that it is not (Surani, Barton \& Burling, 1980; Pratt, Chakraborty \& Surani, 1981; Petzoldt, Burki, Illmensee \& Illmensee, 1983).

The values for $G_{1}, S$ and $G_{2}+M$ found here for the third and fourth cell cycles of mouse development are compared in Table 2 with published values for the first four cell cycles. In common with the three other reports of which we are aware, we find that $G_{1}$ of the third cell cycle is short (about $1 \mathrm{~h}$ ), that the $S$ phase lasts about $7 \mathrm{~h}$ and that $\mathrm{G}_{2}+M$ is variable, lasting between 2 and $5 \mathrm{~h}$ (Sawicki, Abramczuk \& Blaton, 1978; Streffer et al., 1980; Molls et al., 1983). Since these various studies used different mouse strains, different ovulation procedures, and different techniques for evaluating the lengths of each phase, the agreement amongst the reports is striking. The fourth cell cycle is similar to the third, but has a slightly longer $G_{1}$, a similar $S$ and a shorter but variable $\mathrm{G}_{2}+\mathrm{M}$. Both of these cell cycles differ markedly from cell cycles 1 and 2, and do so principally in the length of the $G_{1}$ phase of the first cell cycle, which is reported conflictingly to be either very short or long, and in the lengths of the $G_{2}+M$ phases of the first and second cycles which are also reported as varying considerably, in some cases being rather long (Table 2).

The wide range of estimates for $G_{1}$ of the first cell cycle probably arises in part because of lack of precision in the timing of fertilization and in part because of the atypical events occurring over this period. Fertilization is followed by completion of meiosis II, which takes about $1-2 \mathrm{~h}$ (Maro, Johnson, Pickering \& Flach, 1984), and therefore $G_{1}$ begins with formation of the second polar 
body. Moreover, whereas in normal mitotic cell cycles the nuclear membranes form immediately on entry into interphase, in the 1-cell zygote pronuclear membrane assembly is delayed by a further $2-4 \mathrm{~h}$. Considerable refashioning of the sperm-derived chromatin, including replacement of the sperm protamines with oocyte histones, must occur and may account for this uncoupling of nuclear membrane formation from entry into interphase. In most of the reported studies, $G_{1}$ is taken to include completion of meiotic maturation, the period of membrane-free 'pronuclear' chromosome clusters as well as the pre-S pronuclear phase. A long $G_{1}$ compared with the second, third and fourth cell cycles is not therefore surprising.

The greatest variability both between and within the studies recorded in Table 2 occurs in $\mathrm{G}_{2}+\mathrm{M}$ for each of the first four cell cycles. It is possible that whilst the variability between results of studies for the first two cell cycles may reflect real differences between mouse strains, it could also represent in part an artefact due to the extreme sensitivity of embryos to environmental stress over this period. Our own unpublished observations suggest that lowering of the temperature from 37 to $20^{\circ} \mathrm{C}$ at any point between the $\mathrm{S}$ phases of cell cycles one and two leads to prolonged $\mathrm{G}_{2}+\mathrm{M}$ phases in both of these cell cycles. When such a temperature drop is avoided, $\mathbf{G}_{2}+\mathbf{M}$ of the first cell cycle is about $2-3 \mathrm{~h}$ and of the second cell cycle about $12 \mathrm{~h}$, i.e. at the low end of the estimates in Table 2 and similar to their lengths in vivo. Indeed, in many mouse strains, $G_{2}$ of the second cell cycle appears to be prolonged indefinitely when embryos are placed in vitro, the so-called '2-cell block' (Goddard \& Pratt, 1983). Despite the possibility that $\mathrm{G}_{2}+\mathrm{M}$ of the second cell cycle may be susceptible to artefactual lengthening, even under optimal conditions it is clearly much longer than $G_{2}$ of preceding and succeeding cycles. It may be significant that, over this period, maternal mRNA is largely destroyed, embryonic mRNA is both synthesized and translated into protein, and this protein is necessary and sufficient to carry the development of the embryo to the late 8-cell stage (Flach, Johnson, Braude, Taylor \& Bolton, 1982; Giebelhaus, Heikkila \& Schultz, 1983; Bolton et al., 1984). Thus, the second cell cycle marks a critical step in the early differentiative process, and both the length of its $G_{2}$ phase and its susceptibility to artefactual lengthening may reflect this.

It is less likely that the variable $G_{2}+M$ phase observed here in the third and fourth cell cycles also results from experimentally introduced distortions, as care was taken in this study to avoid temperature drops. An increasing asynchrony of blastomeres within a single embryo has also been noted under a number of conditions by others (Barlow et al., 1972; Kelly et al., 1978; Streffer et al., 1980). The results reported here suggest that the main component of this variability occurs in the last part of each cell cycle. At least one cell feature that influences the rate at which a blastomere progresses through its cell cycle is its size (Ziomek \& Johnson, 1980; MacQueen \& Johnson, 1983) although cell shape may also exert some influence (Surani \& Barton, 1984). The short $\mathrm{G}_{1}$, relatively long $S$ and variable $G_{2}$ phases observed in cell cycles 3 and 4 distinguish these blastomeres not only from those of preceding cycles but also from most other somatic cells in which variation in $G_{1}$ accounts for most of the cell cycle variability observed (discussed by Lloyd, Poole \& Edwards, 1982). The early cell cycles differ from those of somatic cells in that there is no net growth, each blastomere halving approximately in size at each division. Only by the 120 -cell stage is the normal nucleo:cytoplasmic ratio achieved (M. A. H. Surani, personal communication). Cell cycles 3 and 4 therefore seem to occupy an intermediate position between the maternally regulated first and second cell cycles and those characteristic of a differentiated cell. Having a description of the component parts of each cell cycle, we are now in a position to intervene selectively at defined points in each cycle and to examine the consequences for subsequent development (Smith \& Johnson, 1985).

We thank Gin Tampkins, Ian Edgar, Raith Overhill, Gerald Moore, Anne M. Wright and Susan Few for technical assistance and help with preparation for publication; our research colleagues, particularly Dr H. Pratt, for critical comments, and Dr Mike Bennett, Plant Breeding Institute, Cambridge, for use of the microdenistometer. The work was supported by grants from the Cancer Research Campaign and Medical Research Council to M.H.J. 


\section{References}

Abramczuk, J. \& Sawicki, W. (1975) Pronuclear synthesis of DNA in fertilized and parthenogenetically activated mouse eggs. Expl Cell Res. 92, 361-369.

Barlow, P., Owen, D.A.J. \& Graham, C.F. (1972) DNA synthesis in the preimplantation mouse embryo. $J$. Embryol. exp. Morph. 27, 43I-445.

Bolton, V.N., Oades, P.J. \& Johnson, M.H. (1984) The relationship between cleavage, DNA replication, and gene expression in the mouse 2-cell embryo. $J$. Embryol. exp. Morph. 79, 139-163.

Chisholm, J.C., Johnson, M.H., Warren, P.D., Fleming, T.P. \& Pickering, S.J. (1985) Developmental variability within and between mouse expanding blastocysts and their ICMs. J. Embryol. exp. Morph. 86, 311-336.

Domon, M. (1980) Cell cycle-dependent radiosensitivity in two-cell mouse embryos in culture. Radiat. Res. 81, 236-248.

Flach, G., Johnson, M.H., Braude, P., Taylor, R. \& Bolton, V.N. (1982) The transition from maternal to embryonic control in the 2-cell mouse embryo. The EMBO J. 1, 681-686.

Fulton, B.P. \& Whittingham, D.G. (1978) Activation of mammalian oocytes by intracellular injection of calcium. Nature, Lond. 273, 149-151.

Giebelhaus, D.H., Heikkila, J.J. \& Schultz, G.A. (1983) Changes in the quantity of histone and actin messenger RNA during the development of preimplantation mouse embryos. Devl Biol. 98, 148-154.

Goddard, M.J. \& Pratt, H.P.M. (1983) Control of events during early cleavage of the mouse embryo; an analysis of the '2-cell block'. J. Embryol. exp. Morph. 73, 111-133.

Howlett, S.K. \& Bolton, V.N. (1985) Sequence and regulation of morphological and molecular events during the first cell cycle of mouse embryogenesis. $J$. Embryol. exp. Morph. 87, 175-206.

Johnson, M.H. (1985) Three types of cell interaction regulate the generation of cell diversity in the mouse blastocyst. In The Cell in Contact: Adhesions and Junctions as Morphogenetic Determinants pp. 27-48. Eds G. M. Edelman \& J. P. Thiery. John Wiley \& Sons Inc., New York.

Kelly, S.J., Mulnard, J.G. \& Graham, C.F. (1978) Cell division and cell allocation in early mouse development. J. Embryol. exp. Morph. 48, 37-51.

Krishna, M. \& Generoso, W.M. (1977) Timing of sperm penetration, pronuclear formation, pronuclear DNA synthesis, and first cleavage in naturally ovulated mouse eggs. J. exp. Zool. 202, 245-253.

Lloyd, D., Poole, R.K. \& Edwards, S.W. (1982) The Cell Division Cycle. Academic Press, London.

Luthardt, F.W. \& Donahue, R.P. (1973) Pronuclear DNA synthesis in mouse eggs. Expl Cell Res. 82, 143-151.
Luthardt, F.W. \& Donahue, R.P. (1975) DNA synthesis in developing two-cell mouse embryos. Devl Biol. 44, 210-216.

MacQueen, H.A. \& Johnson, M.H. (1983) The fifth cell cycle of the mouse embryo is longer for smaller cells than for larger cells. J. Embryol. exp. Morph. 77, 297-308.

Maro, B., Johnson, M.H., Pickering, S.J. \& Flach, G. (1984) Changes in actin distribution during fertilization of the mouse egg. J. Embryol. exp. Morph. 81, 211-237.

Molls, M., Zamboglou, N. \& Streffer, C. (1983) A comparison of the cell kinetics of preimplantation mouse embryos from two different mouse strains. Cell Tissue Kinet. 16, 277-283.

Petzoldt, U., Burki, K., Illmensee, G.R. \& Illmensee, K. (1983) Protein synthesis in mouse embryos with experimentally produced asynchrony between chromosome replication and cell division. Roux's Arch. devl Biol. 192, 138-144.

Pratt, H.P.M., Chakraborty, J. \& Surani, M.A.H. (1981) Molecular and morphological differentiation of the mouse blastocyst after manipulations of compaction with cytochalasin D. Cell 26, 279-292.

Sawicki, W., Abramczuk, J. \& Blaton, O. (1978) DNA synthesis in the second and third cell cycles of mouse preimplantation development. Expl Cell Res. 112, 199-205.

Siracusa, G., Coletta, M. \& Monesi, V. (1975) Duplication of DNA during the first cell cycle in the mouse embryo. J. Reprod. Fert. 42, 395-398.

Smith, R.K.W. \& Johnson, M.H. (1985) DNA replication and compaction in the cleaving embryo of the mouse. J. Embryol. exp. Morph. 89, 133-148.

Streffer, C., Van Beuningen, D., Molls, M., Zamboglou, N. \& Schulz, S. (1980) Kinetics of cell proliferation in the preimplanted mouse embryo in vivo and in vitro. Cell Tissue Kinet. 13, 135-143.

Surani, M.A.H. \& Barton, S.C. (1984) Spatial distribution of blastomeres is dependent on cell division order and interactions in mouse morulae. Devl Biol. 102, 335-343.

Surani, M.A.H., Barton, S.C. \& Burling, A. (1980) Differentiation of 2-cell and 8-cell mouse embryos arrested by cytoskeletal inhibitors. Expl Cell Res. $125,275-286$.

Whittingham, D.G. (1971) Culture of mouse ova. $J$. Reprod. Fert., Suppl., 14, 7-21.

Ziomek, C.A. \& Johnson, M.H. (1980) Cell surface interaction induces polarisation of mouse 8-cell blastomeres at compaction. Cell 21, 935-942.

Received 30 May 1985 